\title{
AMERICAS: New Video and Print Resources for Teaching About Latin America and the Caribbean
}

\author{
Mark B. Rosenberg, AMERICAS Education Director, \\ Latin America and Caribbean Center, Florida International University
}

Comparative studies scholars have long been frustrated by an inability to communicate adequately the full range of insights about the regions they study. AMERICAS was developed to fill the need for a balanced, up-to-date examination of the complexity, the commitment, the individual and collective action, and the sights and sounds of the people of Latin America and the Caribbean.

The intention behind the series and accompanying books is to provide background and expert analysis of the inherent tensions, challenges, opportunities, and innovations of a region in transition. AMERICAS also takes advantage of the immediacy of television to offer a visually striking series that will give students new images, knowledge, and a fresh perspective on the region.

Now that the Cold War is over, the United States and Latin America have initiated a new, more positive relationship for the 1990s. Throughout the United States, states and municipalities are looking to Latin America with renewed interest and hope, considering its potential as a key trading partner. Who are the people that make up the 33 sovereign states of Latin America and the Caribbean? How can we help students understand the issues that emerge from this region when it is considered as a whole?

AMERICAS, a 10-part television series and telecourse, is designed as a comprehensive survey of Latin America and the Caribbean. Combining prime-time production values with a new interpretation of the contemporary politics, culture, history, economics, religion, and social structure of the region, AMERICAS has been developed by some of the United States's leading Latin Americanists in collaboration with award-winning public television producers.

The series and telecourse will be of special interest to political scientists who teach comparative politics and/or Latin American politics, Latin America's international relations, and development. It includes ten television programs which contain original footage from television crews working throughout the Americas.

Four of the video programs have direct relevance to politics courses, examining critical concepts such as development and national identity, regime transformation, traditional and new challenges to sovereignty, and the national and international dimensions of revolution.

"The Garden of the Forking Paths: Dilemmas of National Development" traces the modern-era development of the nations and national economies of the Americas, with a focus on Argentina that includes the Peron years, the dictatorship of the 1970s, and the Malvinas/Falklands War.

"Capital Sins: Authoritarianism and Democratization" begins with the rapid economic growth of the late 1960 s and early 1970s, spotlighting the methods Brazil's rulers chose to develop the country and how their choices affected the lives of ordinary Brazilians.

"Get Up, Stand Up: Problems of Sovereignty" addresses internal and external challenges to sovereignty in the Americas and examines the ways in which several nations cope with the dilemma of maintaining economic and cultural sovereignty in the face of strong pressures, both foreign and domestic. It takes place in Colombia, Jamaica, and Panama, exploring a wide range of threats to sovereignty, from narco-terrorism to foreign intervention.

"Fire in the Mind: Revolutions and Revolutionaries" looks at revolutionaries in the region today, with a special emphasis on the former guerillas in El Salvador and the current movement in Peru, and links these movements to the revolutions in Cuba and Nicaragua.

The other six programs in the complete series are: "Continent on the Move: Migration and Urbanization"; "Mirrors of the Heart: Race and Identity"; "In Women's Hands: The Changing Roles of Women"; "Miracles Are Not Enough: Continuity and Change in Religion"; "Builders of Images: Latin American Cultural Identity"; and "The Americans: The Latin American and Caribbean Presence in the United States."

Accompanying print materials, all published by Oxford University Press, include the textbook, Modern Latin America (Third Edition), written by Thomas E. Skidmore and Peter H. Smith; an anthology of readings, AMERICAS: An Anthology, edited by Mark B. Rosenberg, A. Douglas Kincaid, and Kathleen Logan; a book of original essays, AMERICAS: New Interpretive Essays, edited by Alfred Stepan and contributed by leading Latin Americanists who serve on the academic advisory board; and a faculty and study guide.

Development of AMERICAS was supported by the Annenberg/CPB Project, Carnegie Corporation of New York, the John D. and Katherine T. MacArthur Foundation, the Rockefeller Foundation, and the Corporation for Public Broadcasting. AMERICAS has been produced by WGBH Boston and by Central Television Enterprises for Channel $4 \mathrm{UK}$, in association with the School of International and Public Affairs at Columbia University, the Latin American and Caribbean Center at Florida International University, and Tufts University.

If you would like to see a preview videocassette, you may call 1-800-LEARNER. This same contact number handles orders for the complete series (\$275 on VHS; or $\$ 29.95$ for a single program). The series will air on PBS in the United States early in 1993. 